\title{
Shrimp trawl catches and stomach contents of redfish, Greenland halibut and starry ray from West Greenland during a 24-hour cycle
}

\author{
SØREN ANKER PEDERSEN
}

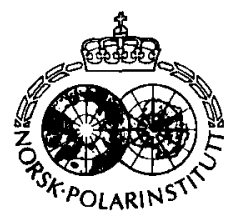

Pedersen, S.A. 1994: Shrimp trawl catches and stomach contents of redfish, Greenland halibut and starry ray from West Greenland during a 24-hour cycle. Polar Research 13(2), 183-196

A total of 179 redfish (Sebastes spp.), 495 Greenland halibut (Reinhardtius hippoglossoides) and 133 starry ray (Raja radiata) stomachs were collected from the catch in four bottom trawl hauls carried out at 6-hour intervals on a shrimp fishing ground off West Greenland in September 1991 . Between 90 and $96 \%$ of the total catch in each of the four trawl hauls consisted of northern shrimp (Pandalus borealis). The fish catches were small and dominated by redfish, Greenland halibut, starry ray and polar cod (Boreogadus saida). The stomach contents of redfish consisted of crustaceans (mysiids, hyperiids and copepods) followed by cephalopods, northern shrimp and redfish. Fish (mainly redfish), cephalopods and northern shrimp were the most important stomach content of Greenland halibut. The stomach content of starry ray consisted mainly of northern shrimp and redfish. Plots of redfish and shrimp sizes found in the stomachs of Greenland halibut and starry ray versus predator size showed only weak associations indicating that availability overruled the importance of size-dependent prey preference. The present study indicates that redfish, Greenland halibut and starry ray feed throughout the 24-hour cycle with no clear diel feeding rhythms.

S.A. Pedersen, Greenland Fisheries Research Institute, Tagensvej 135, 1.tv., DK-2200 Copenhagen N, Denmark

\section{Introduction}

During the last two decades the offshore fishery for northern shrimp (Pandalus borealis) in the Davis Strait has been one of the largest fisheries for this species in the world. In 1992, the nominal catch of shrimp in the offshore area of West Greenland south of $71^{\circ} \mathrm{N}$ increased to about 63,000 tons - the highest level in the history of this fishery (Anon. 1994). Large numbers of fish, mainly redfish (Sebastes spp.), Greenland halibut (Reinhardtius hippoglossoides), and polar cod (Boreogadus saida), but also starry ray (Raja radiata) and long rough dab (Hippoglossoides platessoides) and others, are caught and discarded in the West Greenland shrimp fishery (Pedersen \& Kanneworff in press).

Predation is probably the main source of natural mortality in shrimp populations, and northern shrimp has been described as a major food item for Atlantic cod (Gadus Morhua), Greenland halibut, redfish and eelpouts in the West Greenland waters (Horsted \& Smidt 1956; Horsted \& Smidt 1965; Smidt 1969). Studies of the feeding habits of redfish, Greenland halibut and starry ray on West Greenland shrimp grounds have recently been described by Pedersen $\&$ Riget (1993) and Pedersen (in press). These studies analyse the stomach contents of fish collected mainly during the day. However, diel feeding rhythms are common in many teleosts and diel feeding patterns have been described for tropical and temperate fishes (Helfman 1993). In order to assess the daily rate of food consumption in fish populations, it is essential to have information about the diel variations in their feeding habits (Eggers 1977; Pennington 1985; Wootton 1990; Jarre et al. 1991; dos Santos \& Jobling 1992). This paper compares shrimp trawl catches and stomach contents of redfish, Greenland halibut and starry ray collected during a 24 -hour cycle.

\section{Materials and methods}

A total of 179 redfish, 495 Greenland halibut and 133 starry ray stomachs were collected from four bottom trawl hauls carried out at 6-hour intervals 26 and 27 September 1991. The four trawling periods were night (2.00-3.00 a.m.), after sunrise (8.00-9.00 a.m.), day (2.00-3.00 p.m.) and after sunset (7.45-8.45 p.m.) (Table 1, Fig. 1). The 


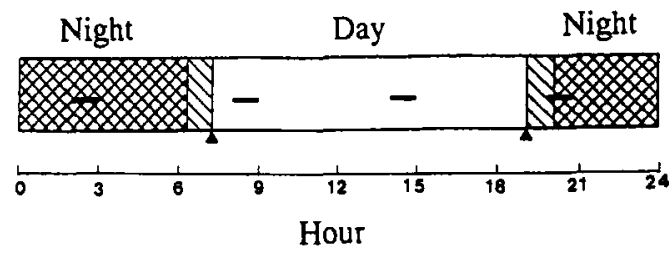

Fig. 1. Allocation of trawls to time of day (local time) and periods of darkness, twilight and daylight at the $24 \mathrm{~h}$ station, 26-27 September 1991. Sunrise (=7.19 a.m.) and sunset $(=7.10$ p.m.) are marked with triangles.

bottom trawling was carried out by $\mathrm{M} / \mathrm{Tr}$ PAAMIUT (722 GRT) on a fixed station north of Store Hellefiskebanken at depths between $450-500 \mathrm{~m}$ (Fig. 2). This area is important for the commercial shrimp fishery. The stomach sampling was performed during a stratified-random trawl survey for shrimp, and the position of the sampling station was chosen mainly because of a good catch of shrimp and fish. The gear used was a Skjervoy $3000 / 20$ shrimp-trawl with bobbin gear and a double-bag with $44 \mathrm{~mm}$ mesh size in the cod-end. The duration of the hauls was held as close as possible to 60 minutes at a speed of 2.5 knots. The wing spread, trawl opening and headline height were about $24 \mathrm{~m}, 286 \mathrm{~m}^{2}$ and $15 \mathrm{~m}$, respectively. The vertical temperature and salinity profile on the fishing station were recorded using a Seabird SBE 9-01 CTD. From the surface to about $70 \mathrm{~m}$, the temperature decreases from about 3 to $-0.7^{\circ} \mathrm{C}$ and increases thereafter to about $2.6^{\circ} \mathrm{C}$ at the bottom (Fig. 3). A more detailed description of the physical oceanography of West Greenland can be found in Buch (1990).

The sampling strategy was to collect stomachs from different length-groups of predators in the catch in each haul. Fish with no signs of regurgitation from the stomach were individually tagged and frozen $\left(<-18^{\circ} \mathrm{C}\right)$ for later examination. The carapace length (CL) of northern shrimp was measured by slide calliper to the nearest $0.1 \mathrm{~mm}$ on subsamples from the catch during the day haul (2.00 p.m.) and the night haul (2.00 a.m.). During each of the four hauls, each total catch (or a subsample) of all species of fish was measured (total length) to the nearest $\mathrm{cm}$ below.

In the laboratory the stomach content was identified to the lowest possible taxon. The degree of digestion of fish prey (DOD) was judged by a six point scale and of invertebrate prey by a four point scale as proposed by Bromley \& Last (1990). Each food category was counted and weighed wet to nearest $0.1 \mathrm{~g}$. Excess liquid was removed mechanically. Whenever the digestive condition permitted, carapace and/or pleuron length of Pandalus borealis were measured with an accuracy of $0.1 \mathrm{~mm}$. Fish prey were measured to the nearest $\mathrm{mm}$ total length and/or the length of the vertebral column was measured. In cases where it was only possible to measure the length of the pleuron and vertebral column, the length of the carapace and total fish length were calculated as described by Pedersen \& Riget (1993).

The relative importance of individual prey taxa was assessed with indices of frequency of occurrence, number and weight (Clark 1985) and a stomach fullness index (Bowering \& Lilly 1992):

Frequency of occurrence: The number of stomachs in which a prey item occurred was expressed as a percentage of the total number of stomachs investigated.

Number: The number of each prey item in

Table 1. Number, size range, mean size and percent empty stomachs of redfish, Greeniand halibut and starry ray stomachs analysed for food by time of collection from the sampling station off West Greenland.

\begin{tabular}{|c|c|c|c|c|c|c|c|c|c|c|c|c|}
\hline \multirow[b]{2}{*}{$\begin{array}{l}\text { Time of } \\
\text { collection }\end{array}$} & \multicolumn{4}{|c|}{ Redfish } & \multicolumn{4}{|c|}{ Greenland halibut } & \multicolumn{4}{|c|}{ Starry ray } \\
\hline & $\begin{array}{l}\text { Number } \\
\text { of } \\
\text { fish }\end{array}$ & $\begin{array}{l}\text { Size } \\
\text { range } \\
(\mathrm{cm})\end{array}$ & $\begin{array}{l}\text { Mean } \\
\text { size } \\
(\mathrm{cm})\end{array}$ & $\begin{array}{l}\text { Per } \\
\text { cent } \\
\text { empty } \\
\text { stomachs }\end{array}$ & $\begin{array}{l}\text { Number } \\
\text { of } \\
\text { fish }\end{array}$ & $\begin{array}{l}\text { Size } \\
\text { range } \\
(\mathrm{cm})\end{array}$ & $\begin{array}{l}\text { Mean } \\
\text { size } \\
(\mathrm{cm})\end{array}$ & $\begin{array}{l}\text { Per } \\
\text { cent } \\
\text { empty } \\
\text { stomachs }\end{array}$ & $\begin{array}{l}\text { Number } \\
\text { of } \\
\text { fish }\end{array}$ & $\begin{array}{l}\text { Size } \\
\text { range } \\
(\mathrm{cm})\end{array}$ & $\begin{array}{l}\text { Mean } \\
\text { size } \\
(\mathrm{cm})\end{array}$ & $\begin{array}{l}\text { Per } \\
\text { cent } \\
\text { empty } \\
\text { stomachs }\end{array}$ \\
\hline $2.00 \mathrm{AM}$ & 47 & $7-21$ & 12.6 & $45 \%$ & 87 & $11-46$ & 24.7 & $13 \%$ & 30 & $16-44$ & 31.2 & $13 \%$ \\
\hline $8.00 \mathrm{AM}$ & 43 & $7-27$ & 14.6 & $61 \%$ & 126 & $10-44$ & 26.9 & $25 \%$ & 28 & $23-44$ & 32.2 & $7 \%$ \\
\hline $2.00 \mathrm{PM}$ & 43 & $8-30$ & 14.1 & $44 \%$ & 188 & $10-43$ & 26.5 & $33 \%$ & 34 & $14-47$ & 26.6 & $3 \%$ \\
\hline $7.45 \mathrm{PM}$ & 46 & $7-32$ & 13.5 & $46 \%$ & 94 & $10-40$ & 24,9 & $21 \%$ & 41 & $9-46$ & 24.0 & $22 \%$ \\
\hline ALL & 179 & $7-32$ & 13.7 & $49 \%$ & 495 & $10-46$ & 26.0 & $25 \%$ & 133 & $9-47$ & 27.5 & $12 \%$ \\
\hline
\end{tabular}


Fig. 2. Location of the sampling station and major physiographic features off West Greenland. The sampling station is marked by a star.

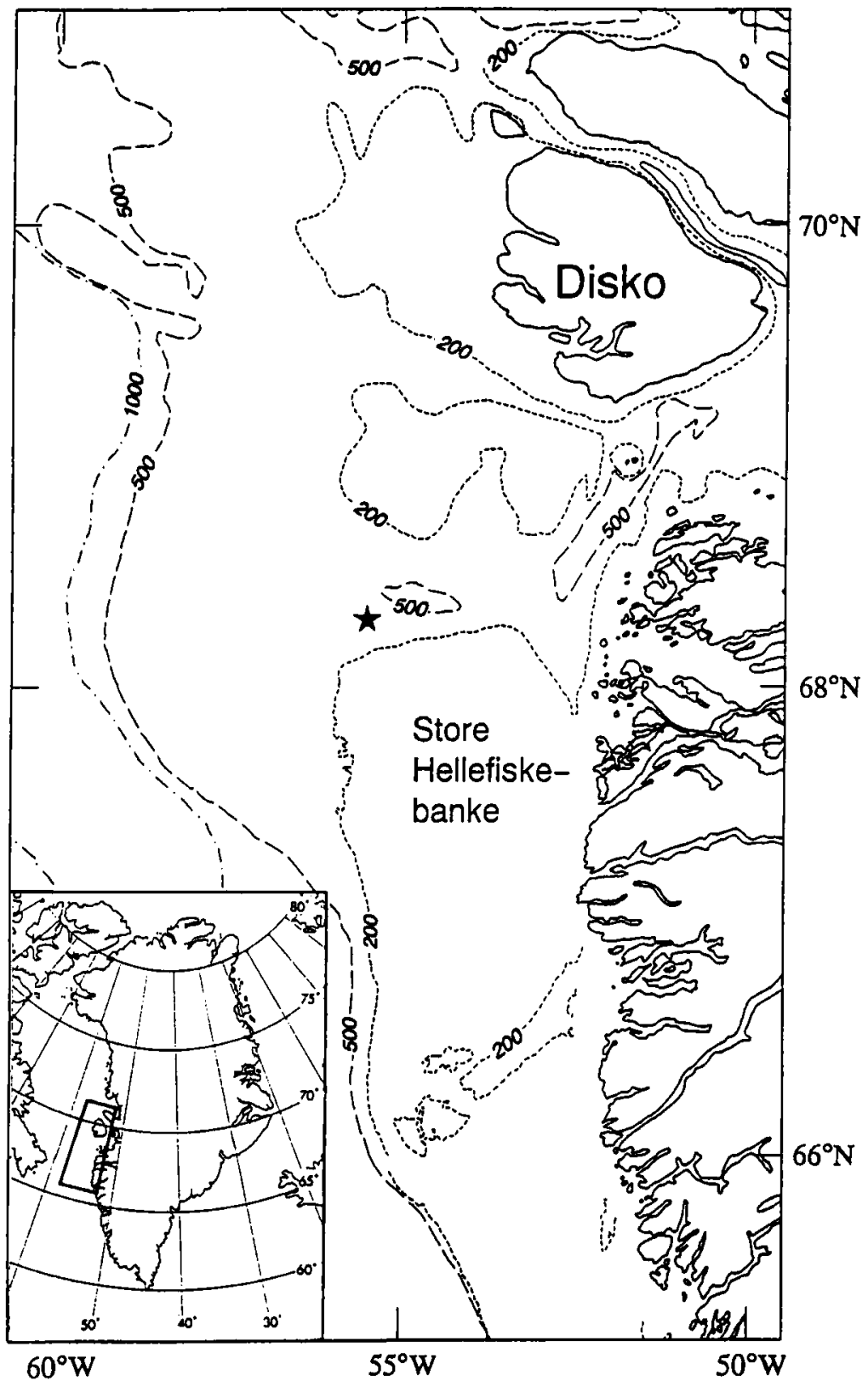

all stomachs in the sample was expressed as a percentage of the total number of food items in all stomachs in the sample.

Weight: The weight of each prey item in all stomachs in the sample was converted to a percentage of the weight of the total stomach contents in the sample.
The mean partial fullness index of prey was calculated as:

$$
P F I_{i}=\frac{1}{n} \sum_{j=1}^{n} \frac{W_{i j}}{L^{3} j} \times 10^{4}
$$

where $W_{i j}$ is the weight of prey $i$ in fish $j, L_{j}$ is the length of fish $j$, and $n$ is the number of fish in the 


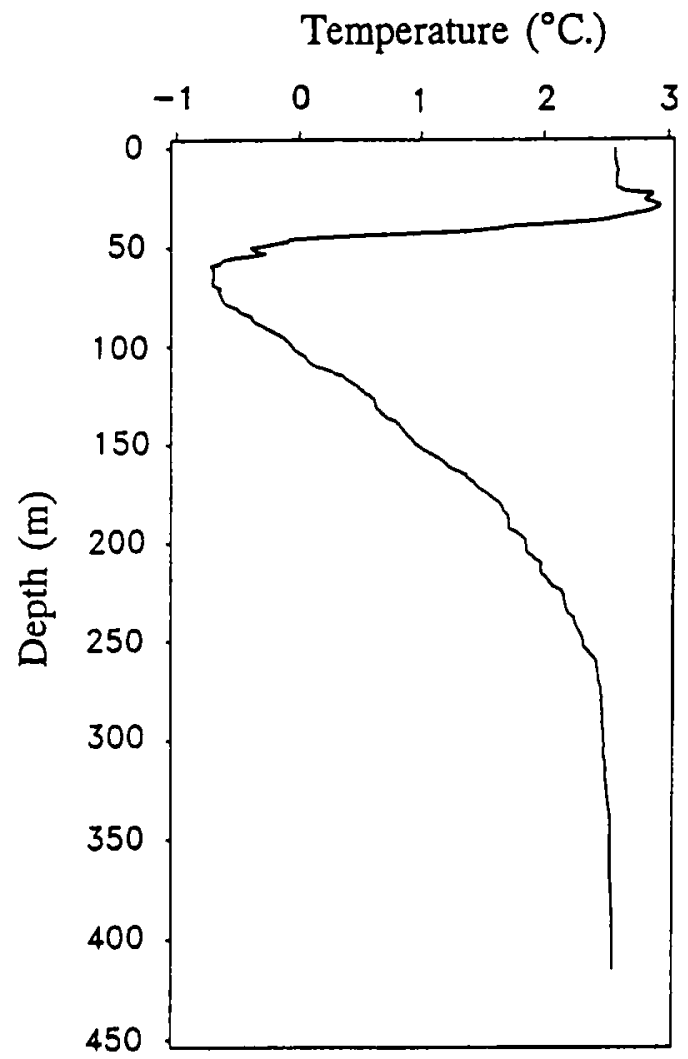

Fig. 3. Temperature profile on the sampling station off West Greenland 27 September 1991.

sample. The mean total fullness index (TFI) was calculated by adding values of mean partial fullness index.
Each index has its advantages and limitations, depending on the question addressed (Hyslop 1980). I used PFI and TFI to emphasise the weight of prey in relation to predator size and to examine stomach content variability related to predator size and sampling time. Plots of the frequency distributions of the TFI data revealed that the TFI of redfish, Greenland halibut and starry ray looked far from normal or log-normal distributed, but was rather exponential distributed. Therefore, the Kruskal-Wallis rank test, a nonparametric method, was used to test for differences between the median TFI in relation to fish size and sampling time. Chi-square $\left(\chi^{2}\right)$ tests $(2 \times 2$ and $p \times q$ contingency tables) were used to test for difference in the probability of an individual having an empty stomach by time of day, and for difference in the size frequency distributions of shrimp and fish from the trawl catches by time of day (Campbell 1975).

\section{Results}

\section{Trawl catches}

Between 90 and $96 \%$ of the total catch in each of the four trawl hauls consisted of northern shrimp (Table 2). There were small variations in the CPUEs of shrimp between the hauls and no clear diel effect. The fish catches were small and dominated by redfish, Greenland halibut, starry ray and polar cod. Most redfish were taken in the day haul at 2.00 p.m. and most Greenland halibut and

Table 2. Catch $\left(\mathrm{kg} \mathrm{h}^{-1}\right)$ of shrimp and fishes by haul on the sampling station off West Greenland, 26-27 September 1991.

\begin{tabular}{lccrr}
\hline & \multicolumn{4}{c}{ Catch $\left(\mathrm{kg} \mathrm{h}^{-1}\right)$ by hauling time } \\
\cline { 2 - 5 } Species & $2.00 \mathrm{AM}$ & $8.00 \mathrm{AM}$ & $2.00 \mathrm{PM}$ & $7.45 \mathrm{PM}$ \\
\hline Shrimp & 1100.7 & 1466.5 & 1274.0 & 1465.0 \\
Redfish & 41.8 & 38.2 & 62.4 & 22.6 \\
Greenland halibut & 14.8 & 30.0 & 46.4 & 18.4 \\
Starry ray & 11.1 & 13.2 & 12.1 & 12.0 \\
Polar cod & 2.5 & 6.3 & 2.9 & 3.2 \\
Eelpouts & 1.4 & 1.5 & 2.7 & 1.1 \\
Sea snails & 1.0 & 2.3 & 1.1 & 1.1 \\
Long rough dab & 0.5 & 1.0 & 1.4 & 0.2 \\
Sculpins & 0.8 & 0.4 & & 0.5 \\
Atlantic cod & 0.2 & & 0.5 & 0.6 \\
Roughhead grenadier & 0.2 & 1.5 & 0.5 & 0.0 \\
Squids & 0.1 & 0.0 & & 0.5 \\
Others & 0.0 & & & 0 \\
\hline
\end{tabular}


Fig. 4. Size-frequency distributions of northern shrimp caught during a day and a night haul on the sampling station off West Greenland.

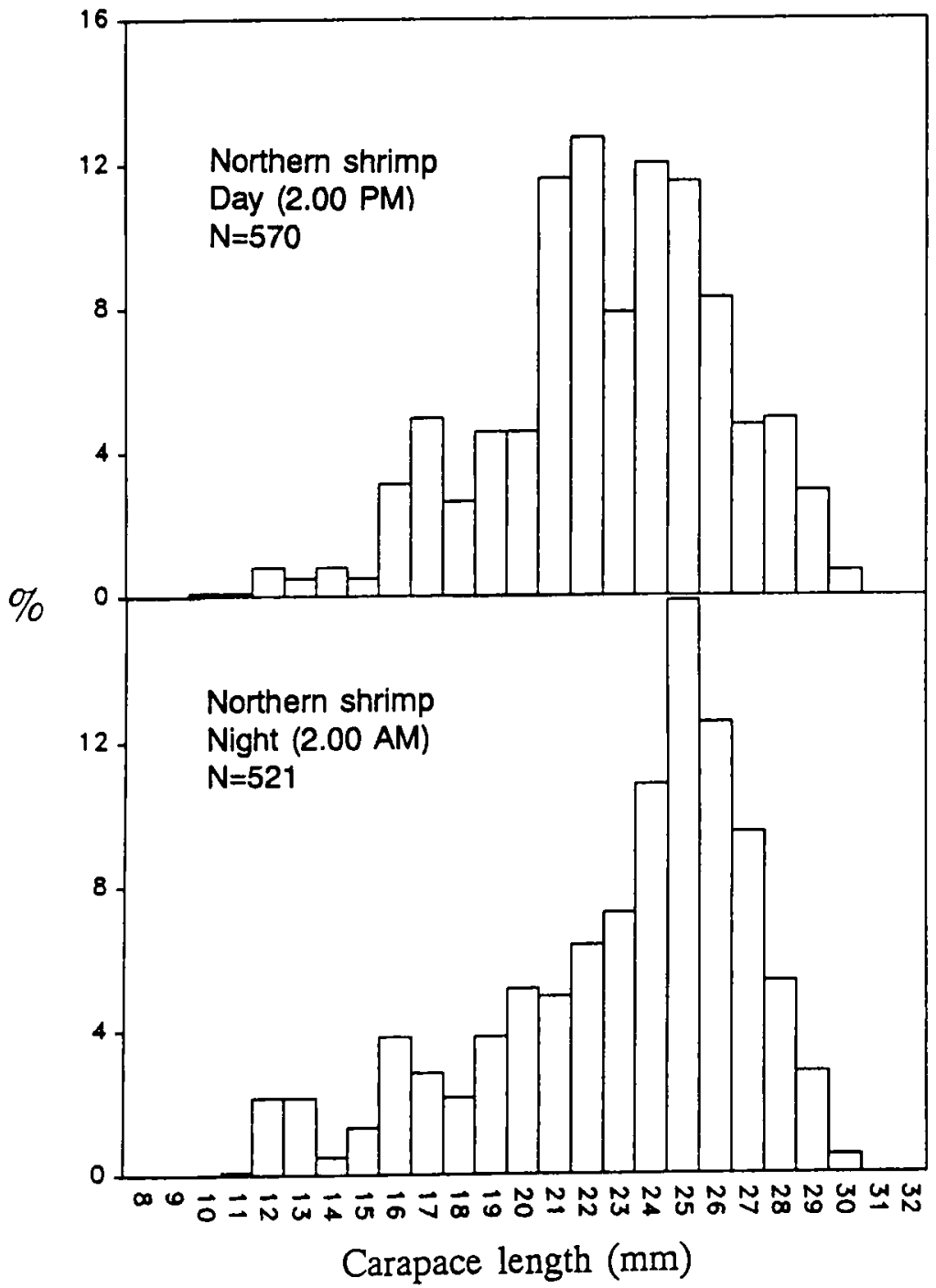

polar cod were taken in both day hauls at 8.00 a.m. and at 2.00 p.m. (Table 2). There was a significant difference $\left(\chi_{18}^{2}=103.4, p<0.001\right)$ between the day and night haul in the size-frequency distributions of shrimp - the prominent modes occurred at $21-22 \mathrm{~mm} \mathrm{CL}$ and $24-25 \mathrm{~mm}$ $\mathrm{CL}$ in the day haul, whereas the lower mode was less represented in the night haul (Fig. 4). For the fishes in the catch there were minor differences in length-frequency distributions by the time of day, and they were combined (Fig. 5).

\section{General description of diet}

During the stomach sampling very few individuals of Greenland halibut and starry ray showed evidence of regurgitation or stomach eversion. However, the majority of the redfish in the trawl catches had their stomachs everted, and only individuals with intact stomachs as judged by eye were selected. Therefore, the reliability of stomach content data from the redfish are questionable. The percentages of empty stomachs regardless of 


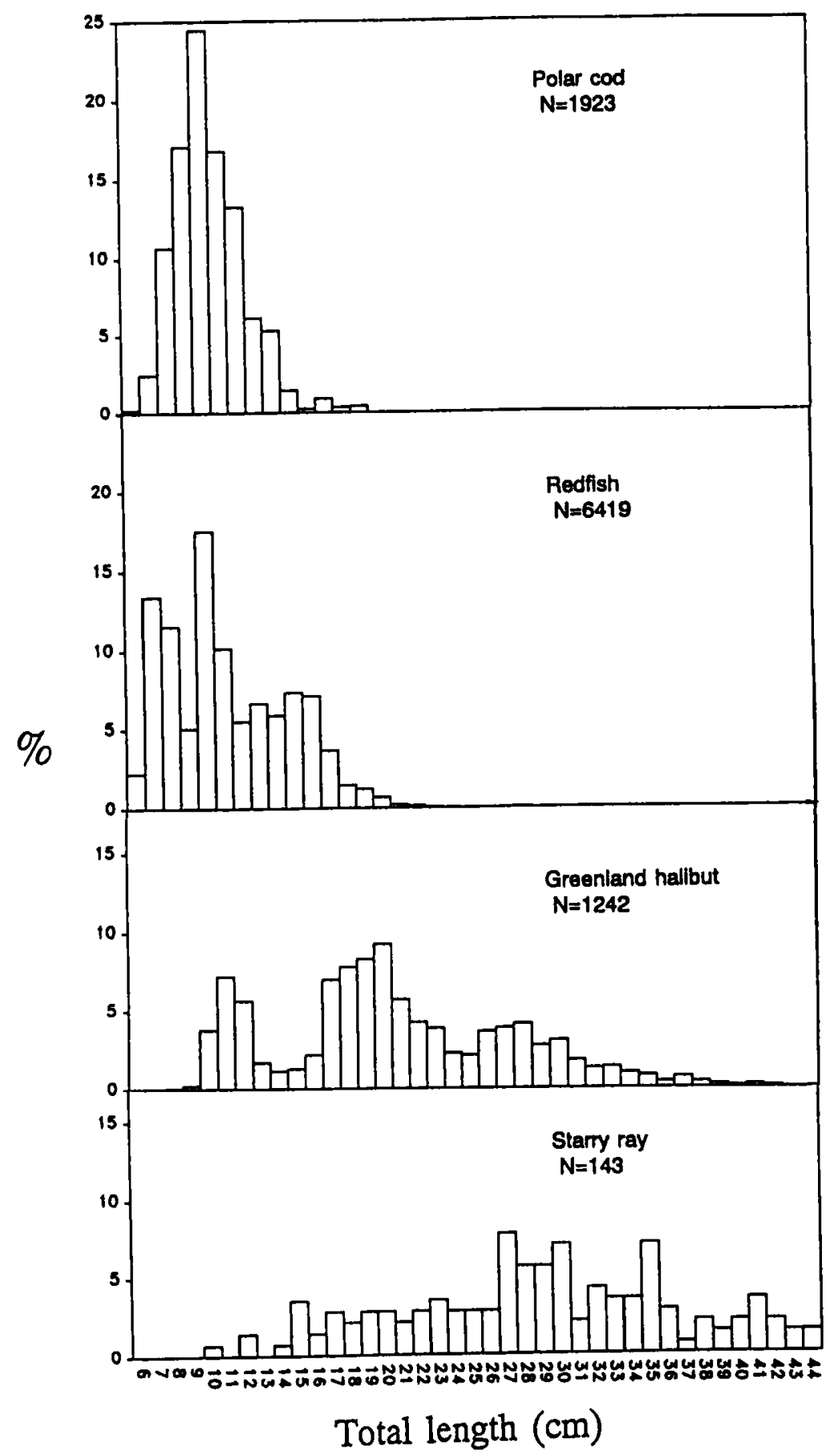

Fig. 5. Combined sizefrequency distributions of the dominant fish species caught during the four haul on the sampling station off West Greenland. 
fish length during the four sampling times varied from 44 to $61 \%$ for redfish, from 13 to $33 \%$ for Greenland halibut and from 3 to $22 \%$ for starry ray (Table 1 ). For redfish $\chi^{2}$-tests showed that there was no significant $(p>0.05)$ difference in the probability of an individual having an empty stomach between the different sampling times (tested in pairs). For Greenland halibut there was a significant higher probability of an individual having an empty stomach during the day at 2.00 p.m. compared to both the night samples at 2.00 a.m. and 7.45 p.m. $\left(\chi^{2}{ }_{1}=12.6, p<0.001\right.$ and $\left.\chi_{1}^{2}=4.2, p<0.05\right)$. For starry ray the probability of an individual having an empty stomach was significantly different between all the sampling times and, therefore, there was a significant lower probability of an individual having an empty stomach during the day (Table 1).

The food of redfish, Greenland halibut and starry ray were identified to 23 taxonomic units (Table 3). The food of redfish consisted of the crustaceans (mysiids, hyperiids and copepods) followed by cephalopods, northern shrimp and redfish. Shrimp had a low occurrence $(2.2 \%)$ in the redfish stomachs but was important by weight (39\%). Fish, cephalopods and northern shrimp were the most important food for Greenland halibut. Of the fish prey, redfish was the most important ( $33 \%$ by occurrence and $46 \%$ by weight) but polar cod and Greenland halibut were also important. The food of starry ray consisted of mainly northern shrimp and redfish.

Table 3. Prey items from stomachs of redfish, Greenland halibut and starry ray caught on the sampling station off West Greenland, 26-27 September 1991. Percentages of occurrence (0), numbers ( $n$ ), and weight $(W)$ and mean partial fullness indices (PFI). (0.0 indicates presence but percentage $<0.05 ; 0.00$ indicates $\mathrm{PFI}<0.005$ ).

\begin{tabular}{|c|c|c|c|c|c|c|c|c|c|c|c|c|}
\hline \multirow[b]{2}{*}{ Prey items } & \multicolumn{4}{|c|}{ Redfish } & \multicolumn{4}{|c|}{ Greenland halibut } & \multicolumn{4}{|c|}{ Starry ray } \\
\hline & $0(\%)$ & $\mathrm{n}(\%)$ & $\mathbf{w}(\%)$ & PFI & $0(\%)$ & $\mathrm{n}(\%)$ & $\mathbf{W}(\%)$ & PFI & $0(\%)$ & $\mathbf{n}(\%)$ & $\mathrm{w}(\%)$ & PFI \\
\hline Polychaeta & & & & & 0.2 & 0.3 & 0.0 & 0.00 & 0.8 & & 1.0 & 0.06 \\
\hline Cephalopoda & 2.2 & 8.9 & 10.3 & 0.04 & 6.1 & 8.5 & 11.4 & 0.30 & 0.8 & & 0.0 & 0.00 \\
\hline Crustacea (total) & 14.5 & 88.7 & 83.7 & 0.71 & 15.8 & 32.0 & 23.1 & 0.35 & 33.1 & 81.4 & 68.3 & 1.34 \\
\hline Copepoda & 1.1 & 11.1 & 2.6 & 0.08 & 0.6 & 3.2 & 0.0 & 0.00 & 3.8 & 17.8 & 0.0 & 0.02 \\
\hline Mysidacea & 6.7 & 37.8 & 27.7 & 0.29 & 1.2 & 1.6 & 0.3 & 0.01 & 11.3 & 32.5 & 0.7 & 0.06 \\
\hline Isopoda & & & & & & & & & 0.8 & & 0.0 & 0.03 \\
\hline Gammaridea & & & & & & & & & 1.5 & 3.8 & 0.0 & 0.01 \\
\hline \multicolumn{13}{|l|}{ Hyperiida } \\
\hline Parathemisto sp. & 0.6 & 4.4 & 0.0 & 0.00 & 2.8 & 5.6 & 0.3 & 0.03 & & & & \\
\hline Unid. Hyperiida & 4.5 & 22.2 & 10.0 & 0.18 & 3.2 & 8.0 & 1.1 & 0.08 & 0.8 & 0.6 & 0.0 & 0.00 \\
\hline Euphausiacea & 0.6 & 2.2 & 0.0 & 0.00 & 0.4 & 0.5 & 0.1 & 0.00 & & & & \\
\hline \multicolumn{13}{|l|}{ Natantia } \\
\hline Pandalus borealis & 0.6 & 2.2 & 17.4 & 0.07 & 4.0 & 6.4 & 13.9 & 0.12 & 12.8 & 12.1 & 25.3 & 0.45 \\
\hline Pandalus montagui & 0.6 & 2.2 & 0.0 & 0.01 & 0.4 & 0.5 & 0.0 & 0.00 & & & & \\
\hline Pandalus sp. & 0.6 & 2.2 & 21.7 & 0.02 & 3.6 & 4.8 & 7.0 & 0.08 & 11.3 & 10.8 & 34.9 & 0.64 \\
\hline Crangonidae & & & & & & & & & & & 1.8 & 0.01 \\
\hline Others and unid. & 0.6 & 2.2 & 0.0 & 0.02 & 0.8 & 1.1 & 1.1 & 0.02 & 3.8 & 3.8 & 4.7 & 0.06 \\
\hline Unidenti. Crustacea & 0.6 & 2.2 & 3.3 & 0.03 & 0.2 & 0.3 & 0.0 & 0.01 & 0.8 & & 0.9 & 0.06 \\
\hline Echinodermata & & & & & & & & & 0.8 & & 0.3 & 0.00 \\
\hline Pisces (total) & 0.6 & 2.2 & 4.3 & 0.01 & 36.8 & 59.7 & 64.5 & 0.80 & 15.8 & 18.4 & 30.1 & 0.44 \\
\hline Cottidae & & & & & & & & & 1.5 & 2.5 & 4.4 & 0.05 \\
\hline Boreogadus saida & & & & & 3.0 & 5.3 & 14.3 & 0.14 & & & & \\
\hline Reinhardtius hipp. & & & & & 0.4 & 0.5 & 0.9 & 0.01 & & & & \\
\hline Sebastes sp. & 0.6 & 2.2 & 4.3 & 0.01 & 32.8 & 50.9 & 45.6 & 0.59 & 14.3 & 15.9 & 23.1 & 0.33 \\
\hline Others and unid. & & & & & 1.2 & 3.0 & 3.7 & 0.06 & 0.8 & & 2.6 & 0.06 \\
\hline Unidentified + slime & 33.0 & & & & & & & & & & & \\
\hline TOTAL* & 179 & 44 & 39.7 & 0.75 & 495 & 377 & 1164 & 1.44 & 133 & 157 & 686.5 & 1.86 \\
\hline
\end{tabular}

* Totals are numbers of stomachs, numbers of prey items, prey wet mass (g), and mean total fullness index (TFI). 


\section{Influence of predator size and sampling time}

Redfish. The relative importance of the prey changed with predator size (Fig. 6). Mysids, hyperiids and copepods dominated the stomach content of small redfish $(<15 \mathrm{~cm})$, whereas shrimp, cephalopods and redfish became more important in the stomachs of larger redfish $(>14 \mathrm{~cm})$. The mean total fullness index (TFI) was generally highest for the smallest redfish $(5-9 \mathrm{~cm})$. No diel feeding rhythms could be revealed from the frequency distributions at the different digestion stages of the prey and the DOD of the prey items was generally high $(>2)$ both day and night. Due to the low number of redfish stomachs examined in each size group, the relatively high frequency of empty stomachs and the low reliability of the redfish stomach content data in general, no tests for variation in mean TFI by fish size or sampling time were made.

Greenland halibut. For small Greenland halibut $(<15 \mathrm{~cm})$ hyperiids was the dominating food whereas cephalopod, redfish, shrimp and polar cod were the dominating stomach content of bigger Greenland halibut ( $>14 \mathrm{~cm}$ ) (Fig. 6). From visual inspection of Fig. 6, the TFI of size group $15-24 \mathrm{~cm}$ is higher compared to the other size groups at all sampling times. A Kruskal-Wallis test showed significant $(p<0.05)$ differences in the median TFI between the fish size groups at 2.00 a.m. ( $\mathrm{n}=86, \mathrm{H}=25.20, \mathrm{p}<0.001)$ and 2.00 p.m. $(\mathrm{n}=188, \mathrm{H}=12.04, \mathrm{p}=0.007)$, but not at 8.00 a.m. $(n=126, H=7.10, p=0.07)$ and 7.45 p.m. $(n=94, H=1.90, p=0.59)$. Therefore, tests for differences in the median TFI between the four sampling times were performed for each size group. There were no significant diel differences in the median TFI for the $5-14 \mathrm{~cm}$ size group $(n=52, H=2.30, p=0.51)$ or for the 35$44 \mathrm{~cm}$ size group $(n=40, H=4.82, p=0.19)$, whereas each of the two size groups 15-24 and 25$34 \mathrm{~cm}$ showed significant diel difference in median TFI $(\mathrm{n}=102, \mathrm{H}=15.30, \mathrm{p}=0.002$, and $\mathrm{n}=300$, $\mathrm{H}=16.17, p=0.001$, respectively) due to significant higher median TFI at 2.00 a.m. (tests without the $2.00 \mathrm{a} . \mathrm{m}$. data showed no significant differences). The higher TFI in the night sample may indicate a higher frequency of feeding during the night. However, comparisons of the frequency distributions at the different digestion stages of invertebrate and fish prey at the time of sampling showed no evidence of a higher frequency of the low digestion stages at night (Fig. 7). A visual examination of DOD data of each prey type by time of sampling revealed no evidence for a diel feeding rhythm.

The size-frequency distributions of redfish and shrimp in the Greenland halibut stomachs showed peaks at $7 \mathrm{~cm}$ and $23 \mathrm{~mm}$, respectively (Figs. 8 and 9). A total of 10 polar cod found in the stomachs could be estimated to length from 8 to $16 \mathrm{~cm}$ (six were 11-12 cm). Plots of redfish and shrimp sizes vs predator size showed only weak associations $(r=0.17, n=86$ and $r=0.12, n=$ 23 , respectively) indicating that availability overruled the importance of size-dependent prey preference. Redfish was prey for Greenland halibut above $15 \mathrm{~cm}$, and although all sizes of Greenland halibut fed on small redfish there seemed to be a maximum size limit of redfish taken which increases with predator size (Fig. 10).

Starry ray. Shrimp was the dominating stomach content of starry ray in all size groups (Fig. 6). There was a weak trend of redfish being more important in starry ray above $24 \mathrm{~cm}$. There were no significant differences in the median TFI between the fish size groups at any of the sampling times, and the Kruskal-Wallis test with all sizes of fish included showed no significant differences in the median TFI between sampling time $(n=$ $126, \mathrm{H}=4.53, \mathrm{p}=0.21$ ). A total of 23 shrimp found in the stomachs could be estimated to carapace length from 4 to $33 \mathrm{~mm}$ (Fig. 11). A total of 10 redfish could be estimated to lengths from 6 to $10 \mathrm{~cm}$ (three were $6.5 \mathrm{~cm}$ and three were $9.5 \mathrm{~cm}$ ). Plots of the frequency distributions of the prey digestion stages showed no diel trends, and the DOD of the prey items was generally high $(>2)$ both day and night.

\section{Discussion}

The composition of the demersal fish community was quite stable throughout the 24-hour period at the locality studied. The high catch of northern shrimp, the order of fish importance $(\mathrm{kg} /$ hour $)$ and the size-frequency distributions of both shrimp and fishes found in this study are normal for this fishing depth and location (Pedersen \& Kanneworff in press).

Diel changes in light conditions in the sea are known to influence behaviour and vertical distribution of many species of fish and invertebrates 


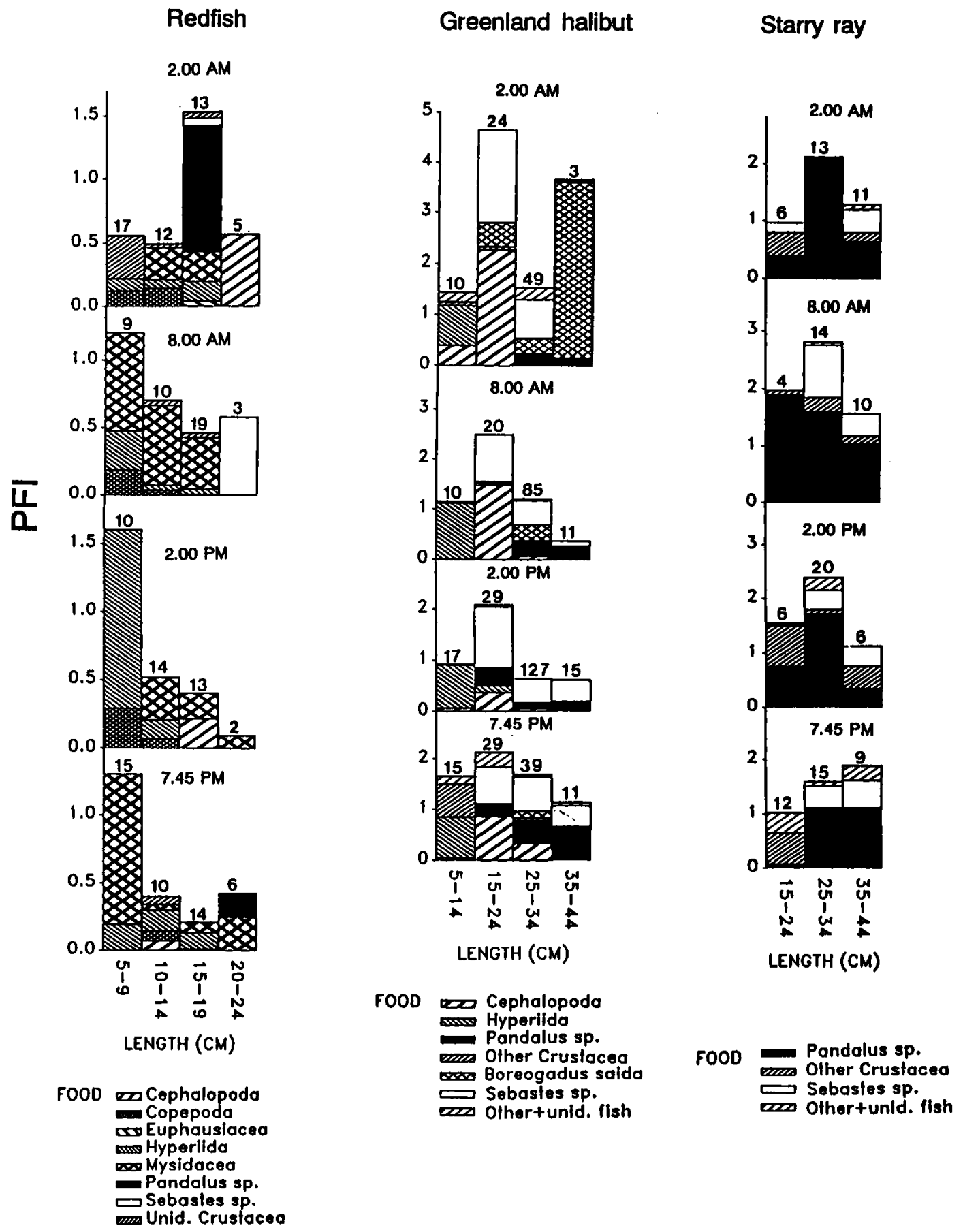

Fig. 6. Mean partial fullness index (PFI) for different food items in stomachs of redfish, Greenland halibut and starry ray by predator length and sampling time from the sampling station off West Greenland. Sample sizes are given at the top. 
Invertebrate

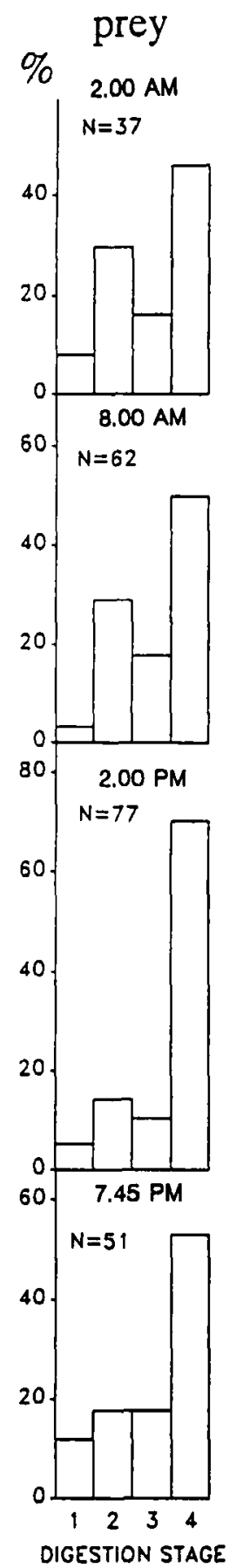

Fish
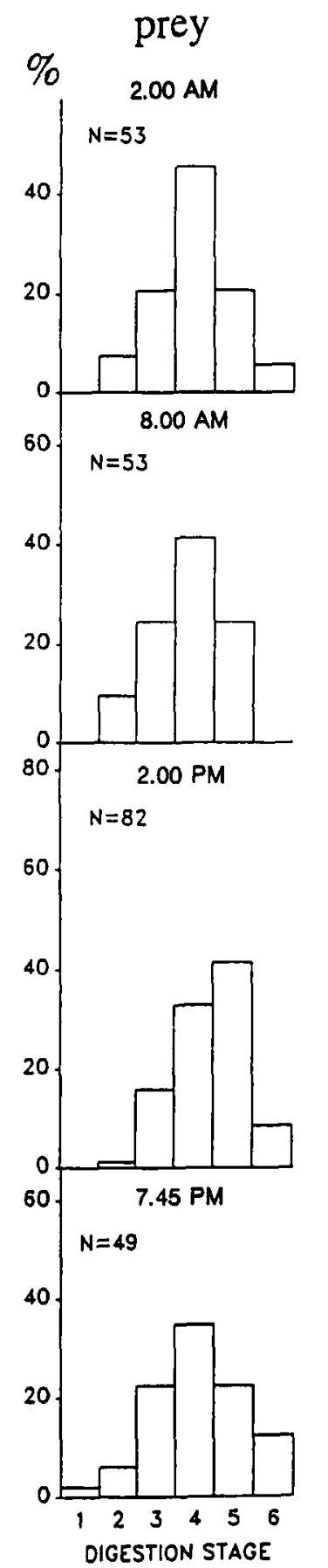

Fig. 7. The frequency of invertebrate and fish prey at the various stages of digestion in Greenland halibut stomachs by sampling time from the sampling station off West Greenland (Digestion stages from Bromley \& Last (1990), $1=$ Intact, no obvious digestion, for invertebrates; 4 = Only fragments remaining and for fish 6 = Just bones).

down to depths of several hundred metres (Longhurst 1976). Thus, diel patterns in stomach contents of fish might be attributable to changes in foraging activity or to changes in availability of the prey. In this study minor diel variation in the CPUE of shrimp was seen; however, in shrimp fishery the highest mean CPUEs of shrimp are normally taken during daytime (Smidt 1978). Differences in the size-frequency distributions of shrimp in the catches between the day and the night haul are also normally seen due to an upward vertical migration during night-time of mainly the intermediate shrimp sizes $(18-22 \mathrm{~mm})$ (D.M. Carlsson pers. comm.). Therefore, the shrimp size-frequency distribution from the daytime haul probably gives the best representation of the shrimp sizes available for the fish predators. In this study there was a trend of more Greenland halibut and polar cod being caught in the daytime hauls.

In August 1992, a study of the vertical distribution of shrimp and fishes during a 24-hour cycle, performed by pelagic trawling in different depth strata in the same area as the present study, found clear upward migrations of shrimp, small Greenland halibut and polar cod from day to night-time (O.A. Jørgensen pers. comm.). However, the redfish, which was only taken in the depth stratum closest to the bottom $(20-30 \mathrm{~m}$ above the bottom) both day and night, showed minor diel vertical migrations.

The diet of redfish, Greenland halibut and starry ray as well as the change in prey type preference with predator size are generally similar to earlier findings from stomach contents of redfish, Greenland halibut and starry ray in West Greenland waters in autumn (Pedersen \& Riget 1993; Pedersen in press). However, compared to the earlier findings the mean TFI of the redfish stomachs in this study were lower. The temperatures at the sampling station are close to the lower temperature limit for the distribution of redfish which is about $2^{\circ} \mathrm{C}$ (Pedersen \& Kanneworff 1994). This may be the reason why the small plankton eating redfish $(<20 \mathrm{~cm})$ are in a low status of feeding and why they are distributed close to the bottom below the cold water in the upper $150 \mathrm{~m}$ of the water column dominated by Polar Water (Fig. 3). The mean TFI of Greenland halibut collected during daytime showed levels similar to earlier findings whereas the mean TFI of the night-time collected were higher (Pedersen \& Riget 1993). From the TFI data of starry ray 
Fig. 8. Combined sizefrequency distributions of redfish in stomachs of Greenland halibut from the sampling station off West Greenland.

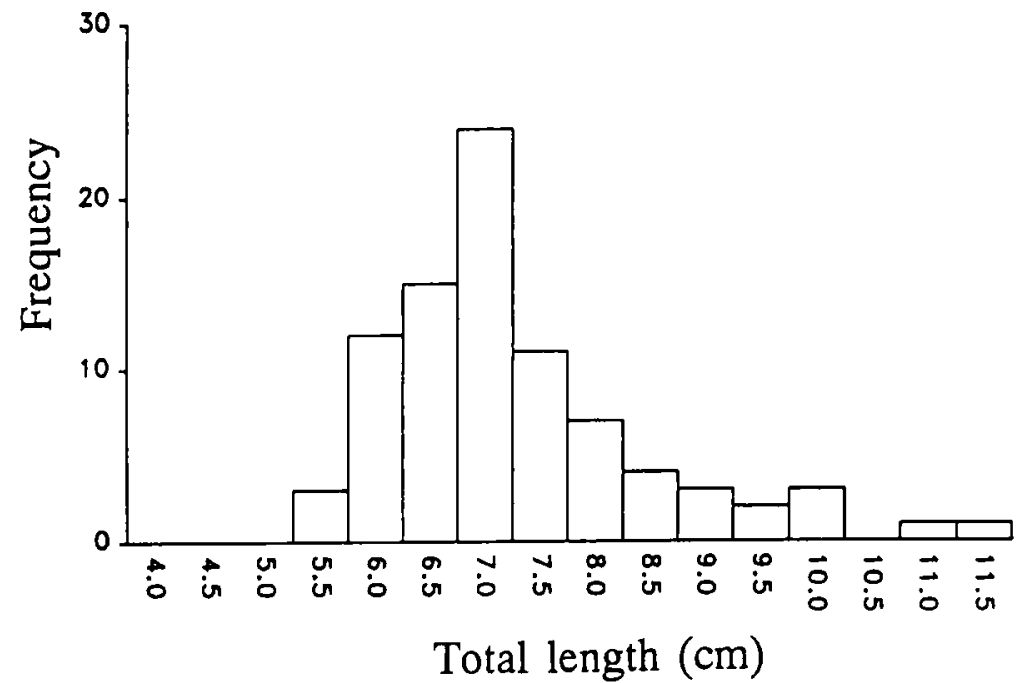

no indication of a sampling time effect was seen. For Greenland halibut there was a higher frequency of empty stomachs during the day whereas for starry ray there was a higher frequency of empty stomachs during the night. The later results may indicate mainly night-time feeding for Greenland halibut and mainly daytime feeding for starry ray. However, comparisons of the frequency of DOD of the dominating prey items by sampling time gave no clear evidence of diel feeding rhythms for either redfish, Greenland halibut or starry ray. There are four likely explanations for this: (1) because of the individual variability in feeding the number of stomachs analysed and, therefore, the number of prey items examined are far too low to detect any diel pattern although

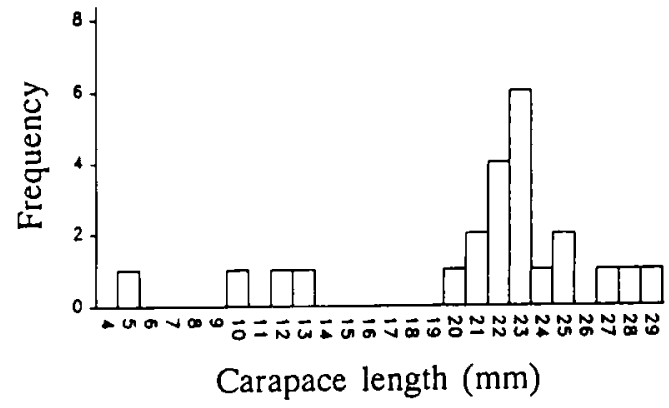

Fig. 9. Combined size-frequency distributions of northern shrimp in stomachs of Greenland halibut from the sampling station off West Greenland. it might exist; (2) the method of freeze storage and thawing the DOD of the different prey items before analysing blurs the possibility of detecting diel feeding rhythms due to secondary decomposition of otherwise fresh prey; (3) Because of large variability in space and time of the feeding activities, one 24-hour cycle from one station is insufficient to detect diel feeding; and (4) the large variability in the time required for predators to digest small and large prey items. According to dos Santos \& Jobling (1991), it may take 3-5 days for a herring or capelin to be evacuated from the stomach of a cod at the temperatures which exist in the area considered in the present study. If it takes several days for the predators in this study to digest a relatively large prey, and additional prey are consumed before the stomach is emptied, then a distinct diel feeding pattern based on analyses of mean TFI may be hard to detect. Even looking for changes in stage of digestion may not be very revealing, unless there is a strong diel pattern in feeding and one has a large sample size, because each prey will be in a given stage of digestion for many hours, and the duration within each stage may vary with the sizes of the predator and the prey and the quantity of other prey in the stomach (G. Lilly pers. comm.). According to Wootton (1990), there may be large variations in the feeding activities of teleosts between days, areas and seasons. The higher TFI and lower proportion of empty stomachs found for Greenland halibut during night-time may be 


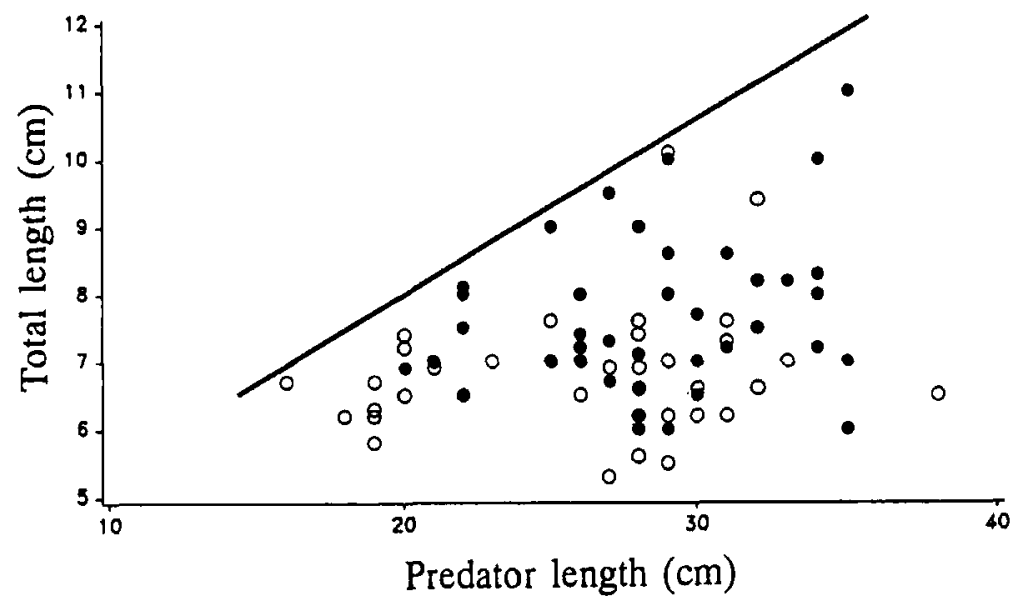

Fig. 10. Plot of total length of redfish found in Greenland halibut stomachs from the sampling station off West Greenland versus predator length. Heavy line indicate upper size limit of prey taken. (Dots = actual measured total length, Circle $=$ calculated total length). explained by higher foraging activity, larger vertical migration and thus lower catches of fish with empty stomachs during bottom trawling at nighttime. However, other studies of feeding habits of Greenland halibut in the eastern Bering Sea and in the northwest Atlantic found no diel patterns in stomach content (Yang \& Livingston 1988; Bowering \& Lilly 1992). For starry ray from the eastern coast of North America, McEachran et al. (1976) found no indication of diel feeding periodicity; large volumes of prey were found during all periods of day. However, in later studies plots of percentage contributed by major taxa per time period revealed that most euphausids occurred in the rays collected during the night and early morning (0.00-12.00 hrs). Earlier studies of the feeding habits of redfish, Greenland halibut and starry ray in West Greenland waters found areal variations in mean TFI for these species, but except for redfish no significant effects of sampling season on mean TFI were found (Pedersen \& Riget 1993; Pedersen in press).

Comparisons of the size-frequency distributions of redfish found in the Greenland halibut stomachs (Fig. 8) and in the catches (Fig. 5) show that the redfish in the stomachs are smaller than in the catches. This difference is due to a combination of availability and prey size preference. If prey size preference were the dominating factor for prey selection, redfish prey in the size range $8-12 \mathrm{~cm}$ should have had a higher frequency of occurrence in the Greenland halibut stomachs than actually seen (see Fig. 10). Therefore, availability may overrule the importance of sizedependent prey preference and small redfish in

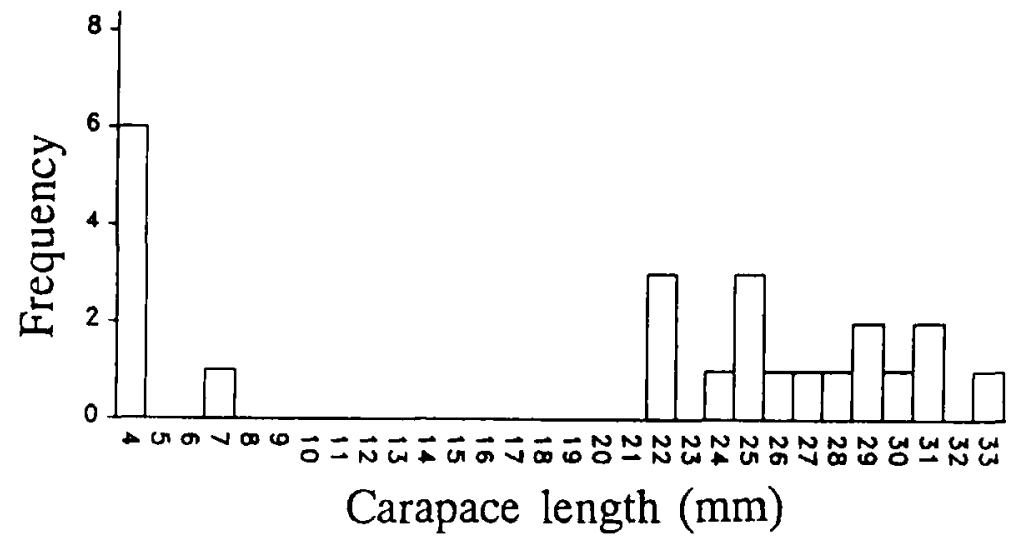

Fig. 11. Combined sizefrequency distributions of northern shrimp in stomachs of starry ray from the sampling station off West Greenland. 
size range $6-8 \mathrm{~cm}$ may be much more abundant and available for Greenland halibut than indicated from the size-frequency distributions of redfish in the catches. A trial fishery during the Greenland shrimp and fish survey in 1993 in the same area as the present study showed that a $20 \mathrm{~mm}$ mesh size in the cod-end of the shrimp trawl caught 3-8 times as many small redfish (6$10 \mathrm{~cm}$ ) compared to the normally used mesh size of $44 \mathrm{~mm}$ (Beck \& Pedersen unpubl.). A $20 \mathrm{~mm}$ mesh size gave minor effects on the CPUEs of larger redfish $(>10 \mathrm{~cm})$. Comparisons of the sizefrequency distributions of northern shrimp found in the Greenland halibut stomachs (Fig. 9) and in the catches (Fig. 4) show similarities between the size-frequency distribution in the stomachs and the size-frequency distribution of the shrimp caught in the daytime haul. This indicates that Greenland halibut feed on the most abundant shrimp sizes in their habitat. The smallest shrimps $(4 \mathrm{~mm} \mathrm{CL})$ found in this study from the starry ray stomachs are probably new settled shrimp of age 0 (Fig. 11). Small shrimps (4 mm CL) were not seen in either the redfish or Greenland halibut stomachs from this or earlier studies probably because they occur closer to the bottom and therefore are more available for starry ray. Shrimp of age group $0(3-5 \mathrm{~mm} \mathrm{CL})$ have been reported from cod stomachs collected from other areas of the northwest Atlantic (Parsons et al. 1986; Lilly \& Parsons 1991). As in the present study Lilly \& Parsons (1991) found shrimp of age group 0 in the same areas and depths as larger shrimp.

The data analysed in this study were obtained from only four trawl hauls performed at 6-hour intervals; therefore, given this weakness no firm conclusions on diel feeding behaviour can be drawn. However, the study indicates that feeding of redfish, Greenland halibut and starry ray is taking place throughout the 24-hour cycle with no clear diel feeding rhythms. Fixed diel cycles of activity may have high selective value (e.g. by reducing competition between species) and are most clearly seen in tropical fish communities (Helfman 1993). In Arctic waters, low temperatures, large annual fluctuations in light, and productivity generally result in lower rates of food consumption, metabolism, stomach evacuation and growth in the fish as compared to fish in tropical and temperate waters. This probably makes diel feeding of less importance and, therefore, less visible. For fish in Arctic waters, opportunistic feeding and the ability to change rhythms in response to changes in the environment and prey availability may be much more important and favoured.

Acknowledgements. - I wish to thank the crew on M/Tr PAAMIUT for help at sea and especially Klaus $H$. Nygård who organised the sampling. Thanks to K. L. Nielsen and Jens Jeppesen for assistance in the laboratory. I also thank G. Lilly and one anonymous referee for many useful comments provided in reviews of this paper.

\section{References}

Anonymous 1994. Northwest Atlantic Fisheries Organization. Scientific Council Reports 1993 (Redbook). Dartmouth, Canada. 234 pp.

Bowering, W. R. \& Lilly, G. R. 1992: Greenland Halibut Reinhardtius hippoglossoides off Southern Labrador and Northeastern Newfoundland (Northwest Atlantic) feed primarily on Capelin (Mallotus villosus). Netherlands J. Sea Res. 29(1-3), 211-222.

Bromley, P. J. \& Last, J. M. 1990: Feeding in the trawl and the consequences for estimating food consumption in natural fish populations. ICES CM 1990/G:35.

Buch, E. 1990: A monograph on the physical environment of Greenland waters. Greenland Fisheries Research Institute. 405 pp.

Campbell, R. C. 1975: Statistics for biologists. Cambridge University Press. 385 pp.

Clark, M. R. 1985: The food and feeding of seven fish species from the Campbell Plateau, New Zealand. New Zealand J. Mar. Freshwater Res. 19, 339-363.

dos Santos, J. \& Jobling, M. 1991: Gastric emptying in cod, Gadus morhua $L$.: emptying and retention of indigestible solids. J. Fish Biol. 38, 187-197.

dos Santos, J. \& Jobling, M. 1992: A model to describe gastric evacuation in cod (Gadus morhua L.) fed natural prey. ICES J. Mar. Sci. 49, 145-154.

Eggers, D. M. 1977: Factors in interpreting data obtained by diel sampling of fish stomachs. J. Fish. Brd. Can. 34, 290294.

Helfman, G. S. 1993: Fish behavior by day, night and twilight. Pp. 479-512 in Pitcher, T. J. (ed.): The behavior of teleost fishes. Croom Helm, London and Sidney.

Horsted, S. A. \& Smidt, E. 1956: The deep sea prawn (Pandalus borealis $\mathrm{Kr}$.) in Greenland waters. Medd. Danmarks Fisk. Havunders $\emptyset$. N.S. l(ll). 118 pp.

Horsted, S. A. \& Smidt, E. 1965: Remarks on effect of food animals on cod behavior. International Commission for the Northwest Atlantic Fisheries, ICNAF Special Publication No. 6, 435-437.

Hyslop, E. J. 1980: Stomach contents analysis - a review of methods and their application. J. Fish Biol. 17, 411-429.

Jarre, A., Palomares, M. L., Soriano, M. L., Sambilay, V. C., Jr. \& Pauly, D. 1991: Some new analytical and comparative methods for estimating the food consumption of fish. ICES Marine Science Symposia 193, 99-108.

Longhurst, A. R. 1976: Vertical migration. Pp. 116-137 in Cushing, D. H. and Walsh, J. J. (eds.): The ecology of the seas. Blackwell.

Lilly, G. R. \& Parsons, D. G. 1991: Distributional patterns of the northern shrimp (Pandalus borealis) in the northwest 
Atlantic as inferred from stomach contents of cod (Gadus morhua). ICES CM 1991/K:41.

McEachran, J. D., Boesch, D. F. \& Musick, J. A. 1976: Food division within two sympatric species-pairs of skates (Pisces: Rajidac). Mar. Biol. 35, 301-317.

Parsons, D. G., Lilly, G. R. \& Chaput, G. J. 1986: Age and Growth of northern shrimp Pandalus borealis off northeastern Newfoundland and southern Labrador. Trans. Am. Fish. Soc. 115, 872-881.

Penneington, M. 1985: Estimating the average food consumption by fish in the field from stomach contents data. Dana 5, 81-86.

Pedersen, S. A. in press: Feeding habits of starry ray (Raja radiata) in West Greenland waters. ICES J. Mar. Sci.

Pedersen, S. A. \& Riget, F. 1993: Feeding habits of redfish (Sebastes spp.) and Greenland halibut (Reinhardrius hip- poglossoides) in West Greenland waters. ICES J. Mar. Sci. 50, 445-459.

Pedersen, S. A. \& Kanneworff, P. in press: Fishes on the West Greenland shrimp grounds, 1988-1992. ICES J. Mar. Sci.

Smidt, E. 1969: The Greenland Halibut Reinhardtius hippoglossoides (Walb.). Biology and exploitation in Greenland waters. Medd. Danmarks Fisk. Havunders $\emptyset$ g. N.S. 6(4), 79148. København.

Smidt, E. 1978: Diurnal variation in shrimp catches on the offshore grounds in ICNAF Divisions 1B and 1C. ICNAF Selected Papers Number 4, 45-46.

Yang. M. S. \& Livingston, P. A. 1988: Food habits and daily ration of Greenland halibut, Reinhardtius hippoglossoides, in the eastern Bering Sea. Fish. Bull. 86(4), 675-690.

Wootton, R. J. 1990: Ecology of teleost fishes. Chapman and Hall, London. 404 pp. 